\title{
MicroRNA-155 Tissue Expression in Patients with Breast CanceratDr Haji Adam Malik Hospital, Medan
}

\author{
Henny Erina Saurmauli Ompusunggu'), Juwita'2), Donny Nauphar3), Sumondang M. \\ Pardede4), Hadyanto Lim5)6), Yahwardiah Siregar5),7) \\ ${ }^{1)}$ Department of Cellular and Molecular Biology, Faculty of Medicine, \\ HKBP Nommensen University, Medan \\ 2)Department of Biochemistry, Faculty of Medicine, Syiah Kuala University, Banda Aceh \\ 3) Department of Biochemistry, Faculty of Medicine, Swadaya Gunung Jati University, Cirebon \\ 4) Department of Pathology, Dr H. Adam Malik Hospital, Medan \\ 5) Master of Biomedical, Faculty of Medicine, North Sumatera University, Medan \\ 6) Department of Pharmacology of the Faculty of Medicine, Methodist Indonesia University, Medan \\ 7) Department of Biochemistry, Faculty of Medicine, North Sumatera University, Medan
}

\begin{abstract}
Background: MicroRNA (miRNA) is non coding-RNA that comprises 18-22 nucleotides. miRNA binds its gene targets in the $3^{\prime}$-untranslated region (3'-UTR), causing direct degradation of mRNA and repressed translationof RNA. MicroRNA regulates various biological processes, including cell proliferation, apoptosis, cell growth, cell differentiation, and metabolism. Various changes have been identified miRNA expression in different types of cancers. This study aimed to describe the expression of miR-155 in patients with breast cancer tissue in Haji Adam Malik Hospital in Medan. Subjects and Method: This was a descriptive study. A total sample was 64 paraffin tissue blocks was taken from female patients with breast cancer at the surgical oncology unit, Haji Adam Malik Hospital in 2013-2014. RNA sample were isolated and checked using a spectrophotometer followed by cDNA synthesis. Then this sample was analyzed for miR-155 expression by using Real Time qPCR. Histopathological grade data were obtained from the medical record.

Results: The miR-155 expression in the breast cancer patients is higher than that in the UniSp6 RNA Spike-in (internal controls). miR-155 expression was 29.64, 28.44, 29.22, in grade-I, grade-II, grade-III breast cancer, respectively. UniSp6 RNA Spike-in was 22.30, 22.89, 23.10, respectively in the control groups. Thus, increase in miR-155 expression was the highest in grade I breast cancer patients.
\end{abstract}

Conclusion: Increased miR-155 expression can be used as a biomarker for early diagnosis and prognosis of breast cancer.

Keywords: miRNA, miR-155, breast cancer.

\section{Correspondence:}

Henny Erina Saurmauli Ompusunggu. Department of Cellular and Molecular Biology, Faculty of Medicine, HKBP Nommensen University, Medan. Email: ompusunggu.henny@gmail.com

\section{BACKGROUND}

Cancer is the third leading cause of death worldwide after cardiovascular diseases and infections (Hauptman and Glavac, 2013). Breast cancer is the second highest incidence in women worldwide having ovarian cancer and about $7 \%-10 \%$ of all malignant tumors. It is estimated that worldwide more than 508,000 women die in 2011 from breast cancer, because most women with breast cancer diagnosed at advanced stages of the disease because early symptoms are not typical (WHO, 2013; Zhao et al., 2012).

Screening for breast cancer allows early diagnosis and potentially reduce mortality. Currently palpation is a tool most reliable screening for breast cancer (Zhao et 
al., 2012). Although today much research done right look for biomarkers as a diagnostic tool and prognostic cancer, but still have not found an effective early detection techniques in order to reduce the number of deaths due to cancer (Hauptman and Glavac, 2013).

Grade histopathology, consisting of grade I, II, and III, the morphological assessment of the degree of differentiation of cancer tissue, which can be used to provide diagnostic and prognostic information in breast cancer (Tavassoli and Devilee, 2003; Dağlar et al., 2010). Histopathological examination method is a method of diagnosing breast cancer terpercayadalam of breast lesions, but it depends on how the sampling and readability of the results by an expert pathology (Oakley and going, 1995). Therefore, the validity of test results is still subjective. Therefore, it required continuous efforts to obtain more objective biomarker, sensitive and specific. One potential candidate cancer biomarkers in the future that has been researched lately is a miRNA.

Micro RNA are non coding-RNA that consists of about 18-22 nucleotides, which is transcribed from the intergenic regions of the genome and the genie who is a new gene regulator (Rodriguez et al., 2004). MicroRNA bind its gene targets in the 3 'untranslated region (3'- UTR), causing direct mRNA degradation or translational repression of mRNA (Valencia-Sanchez et al., 2006; Huntzinger and Izaurralde, 2011). MicroRNA is very stable, the tissue samples were preserved, even several years after formaline fixation and embedded in paraffin, and efficiently extracted from the specimen and is measured in ( $\mathrm{Lu}$ et al., 2012; Szafranska et al., 2008).

MicroRNA has been implicated in the regulation of a wide spectrum of biological processes, including cell proliferation, apop- tosis, growth, differentiation and metabolism. Various changes have been identified miRNA expression in different types of human cancer. In 2005, miRNA expression levels in 76 primary breast cancer tissues and 10 normal tissues using microarray analysis. They found changes in the regulation of $\mathrm{miR}-1 \mathrm{Ob}, \mathrm{miR}-125 \mathrm{~b}, \mathrm{miR}-$ 145, miR-21 and miR-155 are the most significant.

The cancer tissue studies conducted by Volinia (2006) using significance analysis of microarrays (SAM) and predictive analysis of microarrays (PAM) were obtained from six different types of solid tumor miR-21 and miR-155 as a top onkomiR (miRNA as a biomarker of poor prognosis). From the many miRNA are experiencing a change of regulation in breast cancer, the researchers chose miR-155 because it is based on the results research Mar-Aguilar (2013), proved that the expression of miR145 and miR-155 are the most sensitive and specific for breast cancer. From the results of the study found the diagnostic test efficiency were $85.7 \%$ for miR-1ob, miR$89.3 \%$ for $21.89 \%$ for miR-125b, miR$96.4 \%$ for $145.96 \%$ for $\mathrm{miR}-155.78 \%$ for miR-191.

The research question of this study: what is the miR-155 expression in grade-I, grade-II, grade-III breast cancer, in comparison with the control group (UniSp6 RNA Spike-in)?

\section{SUBJECTS AND METHOD}

This was a descriptive study. Samples were 64 paraffin blocks of female patients with breast cancer tissue in surgical oncology at Adam Malik Hospital in 2013-2014. It was taken from the bank block Anatomical Pathology Laboratory of Dr H. Adam Malik who met the inclusion criteria and obtained by purposive sampling. 
Samples were first sliced paraffin blocks as much as 2-4 slices, and then to isolate total RNA, then check the quality and quantity of the isolated RNA using a NanoDrop spectrophotometer. CDNA synthesis is then performed using RT-PCR. Quantification analysis of miR-155 used Real Time qPCR to get value ExiLent Cq using SYBR Green master mix, primer sets of miR-155 (HSA-miR-155-5p), spike uncontrolled primer set (UniSp6 RNA spikeins). This study was approved by the Health Research Ethics Committee of the Faculty of Medicine University of North Sumatra.

\section{RESULTS}

Table 1. Characteristics of research subjects

\begin{tabular}{lc}
\hline \multicolumn{1}{c}{ Characteristics (n) } & Total \\
\hline Age & \\
30-49 & 36 \\
50-78 & 28 \\
Histopathology Grade & \\
$\quad$ Grade I & 15 \\
Grade II & 38 \\
Grade III & 11 \\
\hline
\end{tabular}

Characteristics of research subjects are presented in Table 1, whereas the expression of miR-155 image with UniSp6 RNA Spike-in (as internal control) in breast cancer tissue (value cq) is presented in Figure 1.

In this study, most patients are aged $\leq$ 49 years and is in line with research Wang (2010) which is the subject of research they are also more aged $<48$ years. Breast cancer affects more and more by young women, this is one of them caused by mutations in the genes BRCA1 and BRCA2 that increases the incidence of breast cancer is familial approximately $45 \%$ and of the familial.

The incidence of breast cancer in early-onsetincreased by approximately $80 \%$
(Mattiske et al., 2012; Miki et al., 1994). In addition, the menstrual ages ranging from early ( $<13$ years) and / or experienced menopause older ( $\geq 55$ years) had a higher risk of developing breast cancer (Kumar et al., 2007; Department of Health Affairs, 2009). The increased risk caused by the longer lifetime exposure to the hormones estrogen and progesterone (Tryggvadottir et al., 2003; Wrensch et al., 2003; Ostad and Parsa, 2011). Hormon estrogen and progesterone can trigger the proliferation of breast epithelial cells to become cancerous (Anderson, 2002)

Wang et al., (2010) and $\mathrm{Lu}$ et al., (2012), states the dominant subject of their study on grade II and III. Most women with breast cancer diagnosed at advanced stages of the disease because early symptoms are not typical (Zhao et al., 2012).

Based on Figure 1, we can see the results of the paraffin blocks of breast tissue of women with breast cancer found an increased expression of miR-155 in all of the study subjects either grade I, grade II and grade III compared with UniSp6 internal controls.

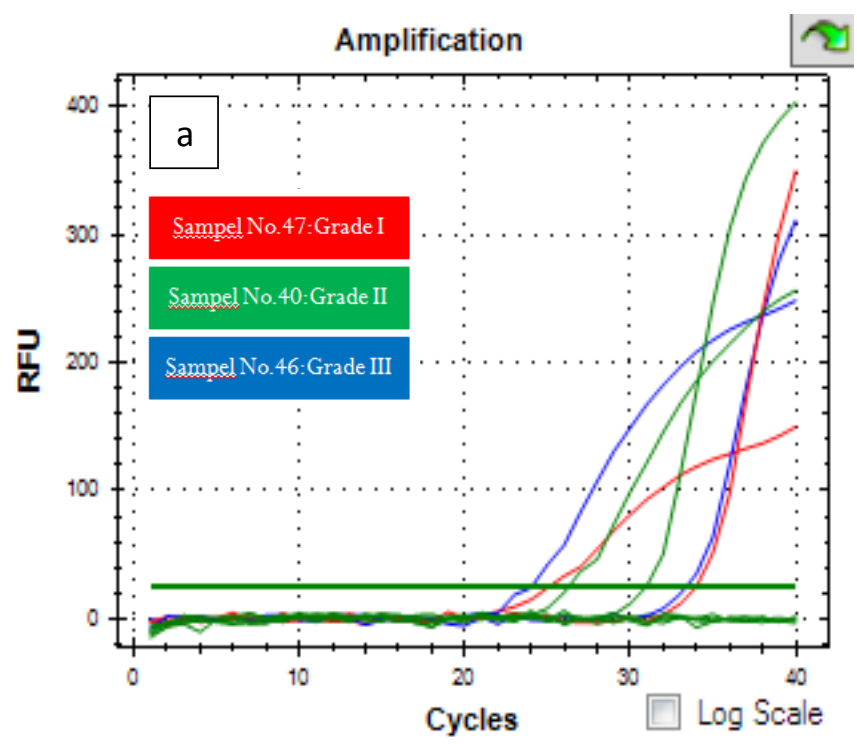



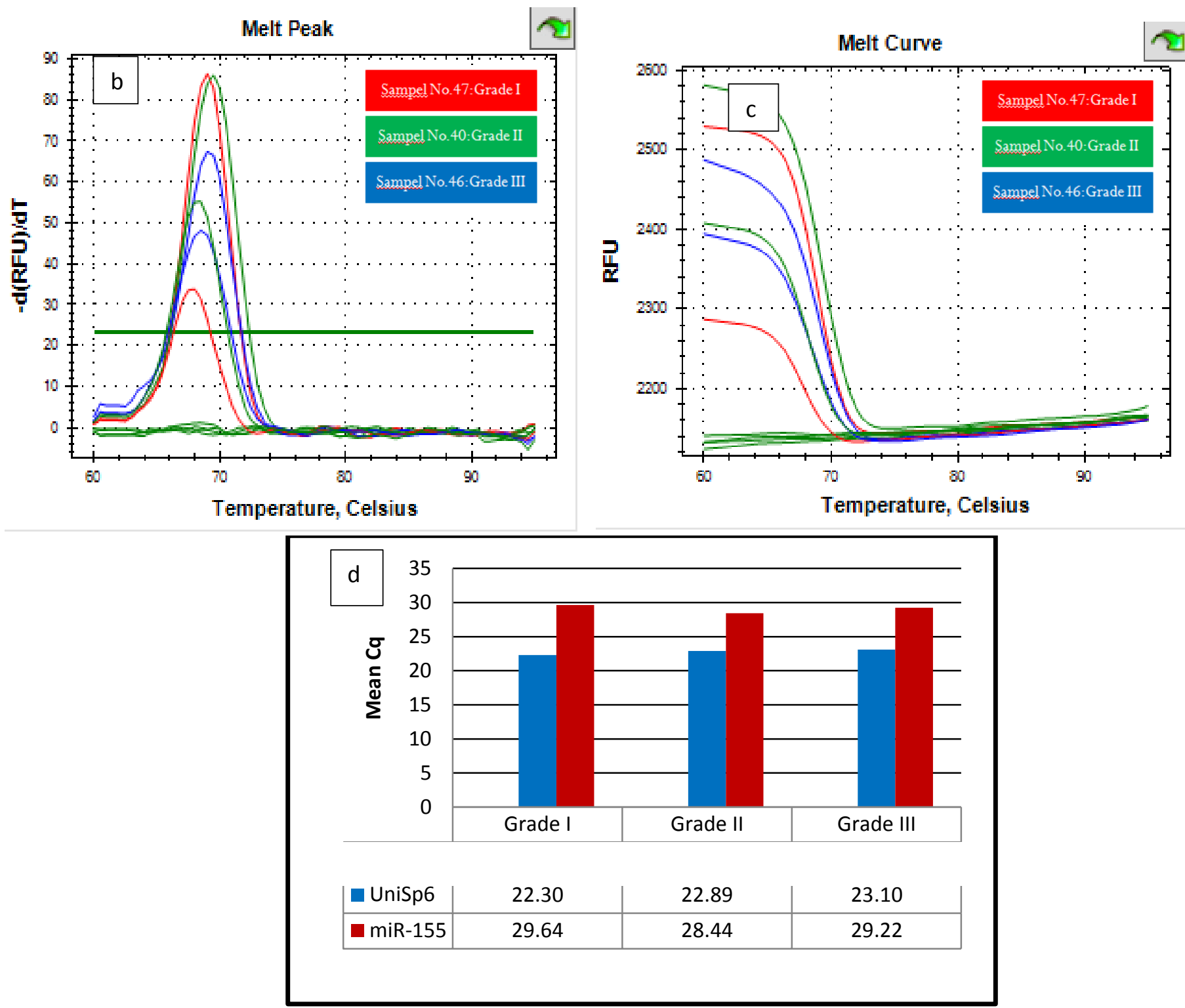

Figure 1. (a) Real Time qPCR quantification of miR-155 and UniSp6 RNA Spike-in (as internal control) -Value cq, (b) Melt Peak miR-155 and UniSp6 RNA Spike-in,

(c) Melt Curve Mirza 155 and UniSp6 RNA Spike-in, (d) Expression of miR-155 with UniSp6 RNA Spike-in on breast cancer tissue (value Cq)

\section{DISCUSSION}

The results of this study are consistent with those of $\mathrm{Lu}$ (2012). Lu's study identifies miR-155 expression using the Real Time qPCR.In the Lu study, miR-155 expression was 5 -times higher in breast cancer than that in normal breast tissue, and it was statistically significant ( $\mathrm{p}<0.05$ ).

Likewise, the miR-155 expression was 5-6 times higher in the plasma of breast e-ISSN: 2549-0265 (online) cancer than that in normal female plasma, and it was statistically significant $(\mathrm{p}<0.05)$.

This finding is also consistent with that of one Wang (2010). In Wang's study, the miR-155 expression was higher in both tissue sample and blood sample in patients with benign breast tumors, grade II, and grade III breast cancer patients, than that of normal controls, and it was statistically significant $(\mathrm{p}<0.05)$. 
From the study it was also found a strong correlation $(\mathrm{r}=\mathrm{0} .85)$ between the miR-155expression in tissue and serum.

In another study conducted by MarAguilar (2013), it was also found that themiR-155expression in the serum of breast cancer patients was significantly higher than the miR-155 expression in the serum of normal women, and it was statistically significant $(\mathrm{p}<0.001)$.

This study also found that miR-155 expression had high sensitivity (94.40\%) and high spesificity (100\%) when compared with the gold standard histopatology assessment. This means that the false negative rate is very low, while the false positive rate is zero.The efficiency of miR155 expressionas diagnostic test was high (96.4\%).

This findings further reaffirm that the miR-155 expression in serum reflects the condition of the miR-155 expression in the network. Further, this findings confirm that the examination of serum miR-155 as a diagnostic method is minimally invasive and accurate.

These results support the miR-155 expression as a potential biomarker for early detection, early diagnosis, and prognosis of breast cancer. But further studies are needed to provide more evidence.

This study found that themiR-155 expression on the whole network of breast cancer patients is higher than that of UniSp6 RNA Spike-in (i.e. internal controls). In particular, the miR-155 expression were highest in grade I breast cancer patients.

The researchers of the current study suggest that further studies be conducted to compare the miR-155 expression in tissues and serum of patients with benign breast tumor, grade I, II, and III breast cancer,and with different histopatologyc types (ductal and lobular types).
Research in miR-155 expression can be used to develop an accurate and less invasive peripheral blood-based biomarker for the detection, early diagnosis, and prognosis of breast cancer metastasis.

\section{REFERENCE}

Anderson (2002). Progesterone receptors animal models and cell signaling in breast cancer: The role of estrogen and progesterone receptors in human mammary development and tumor genesis. Breast Cancer Res; 4: 197201.

Dağlar G, Yuksek YN, Gozalan AU, Tutuncu T, Gungor Y, Kama NA (2010). The prognostic Value of Histopatological Grade in the Outcome of Patients with Invasive Breast Cancer. Turk J Med Sci; 40 (1): 7-15.

Hauptman N, Glavac D (2013). MicroRNAs and Long Non-coding RNAs: Prospects in Diagnostics and Therapy of Cancer. Radiol Oncol, 47 (4): 311-318.

Health Department (2009). Prevention of Cervical Cancer and Breast Cancer. http://www.pppl.depkes.go.id/_asset /_download/bukusaku_kanker.pdf. April 10, 2014.

Huntzinger E, Izaurralde E (2011). Gene Silencing by MicroRNAs: Contributions of Translational Repression and mRNA Decay. Nature, 12: 99-110.

Iorio MV, Ferracin M, Liu CG, Veronese A, Spizzo R (2005). Deregulation MicroRNA Gene Expression in Human Breast Cancer. Cancer Res, 65 (16): 7065-7070.

Kumar V, Cotran RS, and Robbins SL (2007). Textbook of Pathology Robbins. Female genital system and breasts: Breast. EGC. Jakarta.

Lu Z, Ye Y, Jiao D, Qiao J, Cui S, Liu Z (2012). miR-155 and miR-31 are diffe-

e-ISSN: 2549-0265 (online) 
rentially Expressed in Breast Cancer Patients and are correlated with the estrogen receptor and progesterone receptor status. Oncology Letters, 4: 1027-1032.

Mar-Aguilar F, Mendoza-Ram'ırez JA, Malag'on-Santiago I, Espino-Silva PK, Santuario-Facio SK (2013). Serum circulating MicroRNA profiling for identification of potential breast cancer biomarkers. Disease Markers, 34: 163-169.

Mattiske S, Suetani RJ, Neilsen PM, Callen DF (2012). Cancer Epidemiol Biomarkers Prevention: The Oncogenic Role of miR-155 in Breast Cancer. American Association for Cancer Research. cebp.aacrjournals.org. Sept 4th, 2013.

Miki Y, Swensen J, Shattuck-Eidens D, Futreal PA, Harshman K (1994). A Strong Candidate for the Breast and Ovarian Cancer Susceptibility Gene BRCA1. Science, 266: 66-71.

Oakley KL, Going JJ. (1995). Slice Specimen Radiography of Cancer in Breast Conserving excisions. J Clin Pathol, 48: 1028-1030.

Ostad SN, Parsa M. (2011). Breast Cancer from Molecular Point of View: Pathogenesis and Biomarkers. Chapter 6 . Faculty of Pharmacy, Tehran University of Medical Sciences.Tehran .http://cdn.intechopen.com/pdfswm/24879.pdf. Apr 10th, 2014.

Rodriguez A, Griffiths-Jones S, Ashurst JL, Bradley A (2004). Identification of mammalian host MicroRNA genes and transcription units. Genome Res, 14: 1902-1910.

Szafranska AE, Davison TS, Shingara J, Doleshal M, Riggenbach JA (2008). Accurate Molecular characterization of Formalin-Fixed, Paraffin-Embedded Tissues by MicroRNA Expression Profiling. JMD, 10 (5): 415-423.

Tavassoli FA, Devilee P (2003). Pathology and Genetics: Tumours of the Breast and Female Genital Organs. WHO Classification of Tumours; 5. IARC Press. Lyon.

Tryggvadottir L, Olafsdottir EJ, Gudlaugsdottir S, Thorlacius S, Jon G (2003). BRCA2 mutation carriers, reproducetive factors and breast cancerRisk. Breast Cancer Res; 5: R121-r128.

Valencia-Sanchez MAV, Liu J, Hannon GJ, Parker R (2006). Control of translation and mRNA degradation by miRNAs and siRNAs. Genes Dev; 20: 515-524.

Volinia S, Calin GA, Liu C, Ambs S, Cimmino A (2006). A MicroRNA expression signature of human solid tumors defines cancer gene targets. PNAS, 103 (7): 2257-2261.

Wang F, Zheng Zhiguo Z, Guo J, Ding X (2010). Correlation and quantitation of MicroRNA aberrant expression in tissues and sera from Patients with breast tumors. Gynecol Oncol doi; 10.1016 /j.ygyno. 2010.07.021: 1-8.

WHO (2013). Breast cancer: prevention and control.http://www.who.int/cancer/detection/breastcancer/en/. 24th Nov, 2013.

Wrensch M, Chew T, G Farren, Barlow J, Belli F (2003). Risk factors for breast cancer in a population with high incidence rates. Breast Cancer Res, 5: R88-R102.

Zhao SY, Wu Q, Gao F, Zhang CB, and Yang XW (2012). Serum MicroRNA-155 as a potential biomarker for breast cancer screening. Chin Sci Bull, 57: 34663468. 